\title{
The Lyrical Illustration of Neo-Romanticism - A Research on Samuel Barber's Music Style
}

\author{
Huang Jia ${ }^{1,}$, Xie Yuan ${ }^{2}$, Jin Xuedong ${ }^{3}$ \\ ${ }^{1}$ Music and Film Academy, Tianjin Normal University, Tianjin, China \\ ${ }^{2}$ Piano Department, Tianjin Conservatory of Music, Tianjin, China \\ ${ }^{3}$ Musicology Department, Tianjin Conservatory of Music, Tianjin, China \\ Email address: \\ huangjia070015@163.com (Huang Jia),534477982@qq.com (Xie Yuan),jinxuedong@tjcm.edu.cn (Jin Xuedong) \\ ${ }^{*}$ Corresponding author
}

\section{To cite this article:}

Huang Jia, Xie Yuan, Jin Xuedong. The Lyrical Illustration of Neo-Romanticism - A Research on Samuel Barber's Music Style. International Journal of Literature and Arts. Vol. 6, No. 2, 2018, pp. 35-38. doi: 10.11648/j.ijla.20180602.12

Received: April 10,2018; Accepted: August 1, 2018; Published: August 13, 2018

\begin{abstract}
Samuel Barber is a well-known contemporary American composer, honored as the outstanding representative of the Neo-Romantic music. The Neo-Romantic characteristics in Barber's music is focused on this paper in order to learn about the living environment and creative background of Samuel Barber. It is illustrated that how skillfully Barber integrate the American national style into his music works for the purpose of discussing the writing features such as the rhythm and chords that performed in his creations. The Neo-Romantic music of Barber's style is summarized in the conclusion. And the Neo-Romantic characteristics in the Barber's music is explored to help those players while playing the Barber's music work, which can provide the basis and reference.
\end{abstract}

Keywords: Samuel Barber, Neo-Romanticism, Lyric

\section{Introduction}

Neo-Romanticism was a modern music genre that is prevalent in the 1970s and 1980s in the west. In general, it stood for a kind of music that requires being tonal, based on traditional functions and sound, and focused on emotional expression. It often referred to the music texture and material of romantic composers in the 19th century besides those above peculiarities. However, to some extent, it was that using some music languages and techniques initiated in the 20th century with a broader and more diverse music style as the background for creation, which was very different from the musical style of the 19th century [1-3]. In the United States, Samuel Barber, referred to as "the prophet of Neo-Romanticism" or "Neo-Romanticism music practitioner", kept in the closely linked with the European tradition, But also adhered to the romantic style. His music works reflected the bond of ideas between traditional and modern music.

\section{Samuel Barber's Biography}

Samuel Barber was a famous American composer and an outstanding representative of the Neo-Romanticism. His music works had a distinct personality and were widely circulated. They were often selected by musicians to be the concert programs, performed at festivals, and becoming more and more influential in the world recently.

Barber began to learn the piano at the age of 6 , cello at seven, and became an organist at Westminster Abbey at the age of 11. Until the age of 14, with the full support of his uncle and mother, Barber got the opportunity of the professional music education in Curtis Music College in Philadelphia. At that time, Barber learned to compose, piano, conductor, and vocal music.

Barber won many awards in his life. In 1928 he won the first prize ---- Barnes Prize of Columbia University with a violin sonata, which rewarded him a travel to Europe for the first time. In 1931, Barber won that prize again with a prelude. In 1932 Barber began to compose cello and piano sonata that was completed in the same year and performed the first time in Philadelphia. Barber had played the piano personally at that premiere. And this exciting and magnificent works received widespread praise. In 1935 and 
1936, Barber won the Pulitzer Prize and Rome Prize. For that reason Barber had been known as "America's most talented and rewarding musical student" and granted into college for music learning in Rome for two years. In 1938, Barber returned to the United States and taught composition and allocators at the Curtis music college. During that period, Barber continued to work on music creation and accomplished a number of famous music works $[4,5]$.

\section{Barber's Music Style}

Barber's music style was generally described as romantic lyricism. Compared with many American composers in the 20th century, he led a different music style from the others. He had never been an innovator of some technique, nor had he moved in pursuit of novelty [6]. He was just immersed in his personal music language, expressing his personal feelings and always maintaining the unique lyricism and drama he wanted to express. Barber once said, "when I wrote music for words, I immerse myself in words and let music flow out of the text. When I wrote an abstract piano sonata or concerto, I was just writing my feelings!" Barber's music is exactly the same ---focused on expressing subjective emotions, which meant that the primary characteristic of Barber's music style was the emphasis on subjective emotion. The autobiographical writing and lyric characteristics of Babel music were obvious evidence for that $[7,8]$. He liked to reflect the artistic ideals and life aspirations of his heart through the theme of legend, fiction and music. In a creation method, Barber often constructed the idea based on the artistic content such as literature, poetry and drama, and loved to create the title music. He was not constrained by the bondage of classical form, with rich variety of topics related to the content, using all kinds of genres that you can't imagine such as symphony, symphonic poem, ballade, farcicality song as well as a variety of instrumental music, giving them more romantic temperament and more personalized processing, thus more fully expressing personal emotions. In addition, regarding the technique of expression, Barber was inclined to pursuit individuation, the processing of emotion, the theme of tone strengthened lyricism factors, such as using singing tones in instrumental music works to strengthen the feelings expressed. It is more specifically that Barber highlighted the using of music elements of some ethnic groups, such as the intonation of national languages, the adoption of folk songs. In Barber's works, he embodied the national consciousness and music characteristics of the United States [9]. That is a way of showing his strong national feelings on the other hand.

Overall, Barber's composing creation was specialized individuation and noticed to express personal emotions, beautiful melody, smooth and harmonious, with traditional harmony, free of using the traditional formal structure, twelve-tone sequence and more tonal music skills. It can be seen that his pursuit of notes and sound, melody flow, harmonious interpretation and rhythm, harmony development interpretation, which represent Barber's music aesthetic orientation and illustrated his creation idea of
Neo-Romanticism.

\section{The Neo-Romanticism Style of Baber in the Background of 20th Century}

"Neo-Romanticism" was popular in the 1970s and 1980s, which was on the basis of traditional functional harmony, tonality music, paying more attention to emotional expression. Composers of this kind music often cited the traditional romanticism of the 19th century music material. On the other hand, however, the works cited the traditional romanticism was not completely the same with the romantic musicians' style of the 19th century. The Neo-Romanticism composers usually applied the style of modern music of the 20th century more frequently, with more rich and varied artistic forms of expression and more characteristics of the style of music creation. That's the reason this music was so called "Neo-Romanticism". And to the point, Barber's the pioneer of this rising " Neo-Romanticism " tide that was developed and prosperous in the next three and four decades. Barber put the modern music creation technique and the traditional romanticism music language into a perfect combination, pay attention to subjective expression of true feelings. His music and other works made an remarkable influence and promote for the development of the whole 20th century music. In this era of diversification, Barber did not abandon traditional classicism and romanticism music blindly but assimilate it. In this respect, it was genius that he made his creation a blend of modern music technique and traditional classicism. So in his works, the modern elements of music doesn't sound so sharp, harsh, it's tender and sweet instead of. This was also why Barber had his reputation and stood for this "Neo-Romanticism" music tide, not the other old school musicians.

One of the great features of Barber's music style was the lyrical character, which was quite different from the avant-garde music in the 20th century. Apparently, Mr. Barber seems to be on the brand of conservative. "Lyric", that was, singing, kinds of emotional expression. Barber's style of music has a distinctive character of singing which the contemporary evaluation of the style of barber's works was often based on. In the west, the main purpose of the lyric music was to express the true feelings of the people, so it was more important to pay more attention to the melody of music in the creation process. This idea run through the whole western music aesthetic thought development. In ancient Greece, music sought the inner unity of the human mind and music, so that only music could purify the human mind. In the middle ages, Christian theology dominated. During the Renaissance period, with the development of music culture, composers began to attach importance to personal feelings. Baroque period, in architecture, sculpture, painting, music, and other areas of the multiple mutual confluence, passion music focuses on performance, and through the breakthroughs inherent sense of balance and harmony to strengthen the music performance. In the time between 17 th to 18 th centuries, there was an 
anti-feudal and anti-church ideological movement, which was called the enlightenment in history. The enlightenment criticized religion, promoted democracy, equality and freedom, and called on people to emancipate their individuality and make bold innovations, and express the inner true feelings of the individual in art freely. Followed the influence of enlightenment in the 19th century, music enhanced the performance of individual emotions. Then time passed away in the 20th century, music was presented a development of diversification. The lyricism of music was no longer the sole purpose of creation that was also integrated into the composer's personal characteristics. In addition affected by the two world wars of the 20th century, the hearts of many people needed to be healed from trauma. So melody can be no longer simply on sex, love or happiness [10]. What the composers of this period wanted to express appeared to be kinds of complex emotions. Therefore, a variety of different styles of different music have been developed. But there was still a part of the composer can't agree with modern music creation concept, followed the traditional classical music creation road, insist on lyrical character, create music with a strong but beautiful melody. These composers pursuit to music given priority to radical, simple and rich-melody characteristics, using music to meet the needs of the people's inner feelings. They were very different from the direction of that Times and therefore regarded as "conservatives". But their works still got many people's acceptance and love. This fact proved that the lyrical character of traditional music has not been eliminated, it was more important and irreplaceable instead of [11]. Lyricism would still play an important role, even in the heavy siege of avant-garde. Samuel Barber's music creation also confirms this important fact.

\section{The Influence of Neo-romanticism on the Development of Music}

The most striking feature of Barber's music was his application of contemporary vocabulary to express ideas of the past centuries. Lyric as a specific style element runs through all the works of barber. Barber had a strongly bigoted attitude about music's mode or form, reflected in his performance of music, which was closely linked to the romantic music style of the 19th century. Major works were rooted in the structure of sonata. It was the reflection of conservative side of Barber's music style that he used traditional structure and tonality and his emphasized on the primordial tone. At the same time, Barber wanted to avoid using the 20th century music technique, which was similar to the 12-tone sequence and atonality. Barber's lyrical style of music works were negated by many composers at that time, but it actually reached a very high artistic realm and attained the love of large audience [12].

Barber made outstanding contributions to music in the 20th century, and his music works provided technical challenges for the players. Meanwhile, the structure framework of music works was based on the model of music in the 18th and 19th century, and the use of harmonic and rhythmic elements requires the understanding of modern vocabulary. Barber, on the other hand, did not hesitate to achieve his purpose in the simplest possible way. Like many other famous works, there was a direct explanation for the understanding of the lyrical style in the piano works of Barber. The most effective performance was understanding the real thoughts of the composer and expressing the inner meaning of the works by the composer. Only in this way can the real value of music works be illustrated perfectly.

In the early 19th century, the romantic music, whether expressing the change of social environment or reflecting the inner world of the composer, was already extremely expressive and quite profound. At the end of the 19th century, Romanticism expanded to the extreme in all aspects such as harmony, orchestra, melody, texture language, rhythm and structure. In the 20th century, with the development of science and technology, musicians in the new century began to explore a different innovation of music. First of all, there were more music presenting modern concepts such as natural sciences, space and space fantasy. Secondly, there were some strange and novel ways for the expression of music, such as: extremely dissonant harmony, melodic fragmentation, unclearly tonality (even atonality). And the rhythm was complicated, the work often appeared to be on complex rhythm, and mixed beat. The advent of electronic music had also led composers to explore new timbre. Therefore, most music often show strange, sharp or noisy sound effects. This was closely related to the background of the Times. At the beginning of the 20th century, the society was experiencing great upheavals, and the two world wars brought great collision and pain to the human mind. The composer sought a new way to express his complex emotions, which was mention above. In addition, with the improvement of modern science and technology, also inspired by a lot of imagination about space, the emergence of electronic music had enabled musicians to try various methods to create music works. Most people at that time focused on the works with the meaning of "innovation". It was in this particular situation, Barber, at the outside public opinion's pressure, still insisted on his own creation concept, expressed inner feelings of music writing, not affected by many genres of music. At that time, his music ideas were not properly understood and supported, even said to be very conservative and backward. It was irony, however, that in the end people can't stand the extreme harsh music stimulus. By the 1970s, people began to expect to hear the beauty of music. Then the traditional music style of classicism and romanticism were valued once again. Barber's music became popular and be played in many concerts and performances as a matter of course.

\section{Conclusion}

Virtually, lyricism was only one of music characters. Musicians shall not cater to the tastes of the audience, be interfered of external factors or distort their real heart thoughts but present their true inner voice in the creative process. No 
matter adopt what kind of writing method, techniques must be made in line with their own creative thoughts and inner true emotional experience, so that music could be able to accurately show out.

Barber said: "In the creation process of new music works, stick to express the inner true feelings, this is what you must abide by, and each composer in shall abide by the principle of." Romain Rolland also said: "The essence of music - its biggest value is embodied in showing people heart's activity, expression of the secret in the deep of one's mind. The most important thing about music is the inner experience and personal feeling. It is the affection that Musicians needs to compose into music." Barber always insisted on his inner feelings, and he chose the best form to express it. Be true to your true feelings and give music the most authentic voice. Barber 's love of music ran through his life, and he devoted almost everything to music. He was the lyricist of the Neo-Romanticism.

\section{Acknowledgements}

This article was supported by the project of Tianjin Normal University Fund (Humanities and Social Science), No: 043- 135202ww1710.

\section{References}

[1] Stanley Sadie. New Grove Music and Musicians Dictionary: Samuel Barber Index. Macmillan Publisher Ltd, 1980.
[2] Nathan Broder. The Music of Samuel Barber [J]. The Musical Quarterly, Vol. 34, No. 3, 1948, P325-335.

[3] Nathan Broder. Current Chronicle New York [J]. Musical Quarterly. 1950, P276-282.

[4] C. Turner. The Music of Samuel Barber [J]. Opera News, 1958, P32-33.

[5] Li Fangmin. Evaluation of Performance Characteristics of Samuel Barber's Piano Suite Commemorative Sketch Op. 28. [J]. Journal of Jiamusi Vocational Institute. 2017. 12: 407.

[6] Xu Lu. Analysis and Research On the Creation Techniques of American Composer Barber's Piano Works [D]. Capital Nor-mal University, 2003.

[7] Wang Juan. American Musical Elements in The Piano Works of Barber [J]. Literat- -ure and Arts. 2010. 6: 56-57.

[8] Niu Yiran. The Fusion of Tradition and Modernity -- A Study on Barber's Nocturne op. 33 [J]. Musical Works. 2016. 04: 161-163.

[9] Jia Ning. The Interaction Effect Between Traditional And New Romantic Music. [D]. Xi'an Conservatory of Music. 2016.

[10] Feng Wei. The Application of Twelve-Tone Technique in Barber Piano Solo [J]. Art Education. 2016. 08: 110-111.

[11] Wang Jiaxing. The Application and Performance Analysis of Contemporary Music Elements in Barber's Piano Work «Wandering» [J]. Song of the Yellow River. 2016. 22: 6-8.

[12] Gao Na. A Study on New Romantic Music Style of Samuel Barber [D]. Hebei Normal University. 2017. 